\title{
Going beyond Border? Intention to Use International Bank Cards in Vietnam*
}

\author{
Dzung Tran Trung PHAN ${ }^{1}$, Thanh Thi Ha NGUYEN ${ }^{2}$, Tuan Anh BUI ${ }^{3}$ \\ Received: July 2, 2019 Revised: July 3, 2019 Accepted: July 17, 2019
}

\begin{abstract}
The paper aims to explore the factors affecting potential users of international bank cards in Vietnam. With milestones treaties being signed CPTPP and EVFTA, Vietnam is now exposing itself to the international open environment. Bank card market is at the core of this wind of change, and that is the reason for us to research the intention to use international bank cards. Given that the decision to choose international bank cards could either be the switch from domestic cards or adopting a brand new card, we develop some specific constructs to reflect that consideration, specifically PE and PD, asides from traditional constructs used in TPB and TAM frameworks. The analysis work is conducted using PLS-SEM approach. Our findings reveals that most of our proposed hypotheses are supported, in which SN plays the most important direct role to INT, while total effect of PU on INT is similar to that of SN. The newly introduced PD negatively and significantly impacts INT, and PE also has a positive impact on INT. The findings suggest that overall, it is important for bank card issuers to have a balance approach to the market, with focus on increasing usefulness and reducing potential disadvantages of international bank cards.
\end{abstract}

Keywords: PLS-SEM, International Treaty, Bank Card, International Bank Card, Vietnam.

JEL Classification Code: G21, G41.

\section{Introduction}

Bank cards offer multiple benefits to owners, and they are gradually take the place of cash in transactions, both offline and online. Regarding geographical characteristics, bank cards could be divided in to (i) domestic cards, which can only be used for domestic transactions and (ii) international

* We would like to thank our collaborators, especially from Foreign Trade University, State Bank of Vietnam, Vietcombank and VIRAC market research agent for providing us with reports, concepts, modification and delivery of surveys.

1 First Author. Vice Dean, Faculty of Finance and Banking, Foreign Trade University, Vietnam. Email: fandzung@ftu.edu.vn

2 Corresponding Author. PhD Student, Lecturer, Faculty of Finance and Banking, Foreign Trade University, Vietnam [Postal Address: 91 Chua Lang Street, Dong Da District, Hanoi, 100000 Vietnam]. Email: thanh.nth@ftu.edu.vn

3 Associate Professor, President, Foreign Trade University, Vietnam. Email: buianhtuan.bgh@ftu.edu.vn

๑ Copyright: Korean Distribution Science Association (KODISA)

This is an Open Access article distributed under the terms of the Creative Commons Attribution NonCommercial License (https://creativecommons.org/licenses/by-nc/4.0/) which permits unrestricted noncommercial use, distribution, and reproduction in any medium, provided the original work is properly cited. bank cards, which can be used for transaction global wide. For developed countries, bank cards should definitely be international cards without arguments, but this is not the case for developing countries, with less exposure to global market, high cash-based transaction rate and low income.

According to Vietnam Bank Card Association Report (2019), until the end of 2018, total number of cards reached 86 million, $12 \%$ higher than 2017, in which the growth of international bank cards is $17 \%$, leading to the increase in market share of international bank card from $11 \%$ to $13 \%$. The change has happened, but not as strong as expected, non-cash transactions take only approximately $5 \%$ of total transactions, demonstrating a strong cash momentum at the moment. Multiple hurdles have been set up against the acceleration of bank card adoption, even in the context of a non-cash economy orientation program from the government and in the context of Vietnam joining new generations FTAs, including CPTPP and EVFTA. With a frontier and opening market, in comparison with its domestic counterpart, international bank card have clear advantages for cross-border minded owners, with the ability of overseas purchase, brand recognition, the ability to purchase item 
when travelling across borders etc., and the reasons for the slow adoption of international bank card is a big question mark. Therefore, what motivates users to adopt international bank cards, either as a brand new user or switch over from domestic products needs an explanation. There is a need for a research to find out what are the determinants of user's adoption toward international bank cards in Vietnam to find the answer for that riddle.

However, the number of current literatures discussing Vietnamese bank card market is still scarce, focusing on epayment and online banking. Pham, Cao, Nguyen, and Tran (2013) mixed different theories, including TRA, TAM, and decomposed TPB to propose a new model for assessment of online banking adoption. Wang and Pho (2009) identified factors affecting online banking intention and found that brand credibility can affect intention to adopt online banking. Lin and Nguyen (2011) compared e-payment adoption in Vietnam and Taiwan based on TAM framework. Giao (2019) used the integration of qualitative and quantitative methodology and found that customers of Vietcombank mainly affected by price and the bank network, therefore the gap for analysis of behavioral intention toward bank card in general, and international bank card specifically is still open.

In order to develop a model to detect potential users' behavioral intention to use international bank cards, besides applying tradition method and constructs from behavioral intention model, which are TPB (Ajzen, 1991) and TAM (Davis, 1989), based on the characteristics of bank cards, we introduce a new construct, called Perceived Disadvantages, and apply PLS-SEM approach for analysis development.

\section{Literature Review and Hypotheses}

In this research, we developed a theoretical model based on the TAM model, which was introduced by Davis (1989) to predict user acceptance of new technologies and combined it with the theory of planned behavior (TPB) (Ajzen, 1991). According to TAM, an individual's behavioral intention is jointly affected by two beliefs: perceived usefulness and perceived ease of use. Perceived usefulness directly influences the behavior intention, besides, perceived usefulness is influenced by perceived ease of use because the easier the system is to use, the more useful it can be (Venkatesh, Morris, Davis, \& Davis, 2003).

\subsection{Perceived Ease of Use (PEU)}

Rogers (2010) defined Perceived Ease of Use (PEU) as the degree to which an innovation is perceived not to be difficult to understand, learn or operate. This term represents the degree to which the potential user expects the target system to be effortless (Davis, 1989). In banking related researches, many scholars have found a significant relationship between PEU and new technology adoption attitudes (Akturan \& Tezcan, 2012). Shaikh and Karjaluoto (2015) concluded that PEU of mobile banking services has a positive correlation with consumer attitude. Raza, Umer, and Shah (2017) discovered that PEU is significantly and positively related to both perceived usefulness and attitude towards mobile banking acceptance. Attitude and intention were also found to be predicted by PEU (Abadi, Ranjbarian, \& Zade, 2012; Alhassany \& Faisal, 2018; Takele \& Sira, 2013). However, Hu, Ding, Li, Chen, and Yang (2019), based on an improved technology acceptance model to find that PEU does not affect users' attitudes toward the adoption of Fintech services in China. Taylor and Todd (1995a) did found no significant impact from PEU to attitudes.

H1a: Perceived Ease of Use has positive impact on
Attitude

There are also empirical evidence that PEU is significantly linked with intention, both directly and indirectly via its impact on perceived usefulness (Venkatesh \& Davis, 2000). Amin (2007) used TAM model to analyze mobile credit card usage intention among Malaysia bank customers, the results suggested that $\mathrm{PEU}$ is an important predictor of customers' intention to use mobile credit card. Rouibah, Ramayah, and May (2011) has found that PEU has a direct positive impact on behavioral intention to use Internet banking in Malaysia. Jahangir and Begum (2008) concluded that PEU influences positively and significantly to customers' intention to use electronic banking services. Abeka (2012) tested the determinants of internet banking adoption in four East Africa Countries and concluded that PEU has a positive and strong effect on customer adoption. In contrast, Al-Sharafi, Arshah, Herzallah, and Alajmi (2017) used PLS SEM to analyze the intention of bank's customers in Jordan and found that PEU could not predict intention to accept and use online banking services. Aboelmaged and Gebba (2013) also confirmed that PEU has no significant influence individual's attitude toward mobile banking adoption.

\section{H1b: Perceived Ease of Use has positive impact on Intention}

Hu et al. (2019), Taylor and Todd (1995b), Rouibah et al. (2011), Al-Sharafi et al. (2017), Rogers (2010), Abadi et al. (2012), and Aboelmaged and Gebba (2013) found that PEU is a direct factor in explaining perceived usefulness. Some other authors have found no evidence of direct impact from 
PEU to intention to use but the impact on perceived usefulness is significant. Lee (2009) and Sanayei and Bahmani (2012) suggested that PEU does not have a direct impact on intention to use, although it affects the perceived usefulness which then leads to stronger acceptance of online banking and internet banking. The effect size $\mathrm{f}^{2}$ of PEU on PU was measured to be very high (Shaikh \& Karjaluoto, 2015), which means PEU has a significant positive impact on PU.

H1c: Perceived Ease of Use has positive impact on Perceived Usefulness

\subsection{Perceived Usefulness (PU)}

Davis (1989) defined Perceived Usefulness (PU) as the degree to which a person believes that using a particular system would enhance his or her job performance. According to $\mathrm{Hu}$ et al. (2019) and Ryu (2018), customers shall adopt the service if they think the service should bring positive impact. Various literatures discussed the impact of $\mathrm{PU}$ on the other constructs. Evidences that PU has a positive significant impact on ATT was found in the following studies (Abadi et al., 2012; Aboelmaged \& Gebba, 2013; Hu et al., 2019; Lee, 2009; Raza et al., 2017; Sanayei \& Bahmani, 2012; Takele \& Sira, 2013)

H2a: Perceived Usefulness has positive impact on Attitude

Taylor and Todd (1995b) and Cheng, Lam and Yeung (2006) found that PU has both direct and indirect impact on customers' intention to service use . Lee (2009) stated that $\mathrm{PU}$ is strongly associated with intention to use online banking in Taiwan. Moreover, it has an indirect influence via attitude on behavioral intention. Sanayei and Bahmani (2012) provided evidence that PU is the first influential factor to explain intention to use internet banking in Iran. Al-Sharafi et al. (2017) found that PU is the second most powerful determinant of customer adoption towards online banking services in Jordan. PU was found to have significant positive effect on Malaysia bank customers' intentions to use credit card (Amin, 2007, 2013).

H2b: Perceived Usefulness has positive impact on Intention

Alongside with TAM, our theoretical model also based on the theory of planned behavior (TPB) (Ajzen, 1991). TPB is an extension of theory of reasoned action (TRA) (Ajzen \& Fishbein, 1980). TPB deals with behavior where individual have incomplete faculty of using one's will or situation where they have incomplete control of their behavior, and has been frequently used to explain potential users's behavioral intention to purchase/adopt a specific product/service. The extension of TRA had led to the formation of TPB with the introduction of a new construct: perceived behavioral control to the earlier variables of TRA (attitude and subjective norms). Therefore, in the TPB framework, a person's performance of certain behavior depends on his or her intention toward that behavior; intention in turn relies on attitudes, subjective norms and perceived behavioral control (Ajzen, 1991).

\subsection{Attitude (ATT)}

Attitude (ATT) refers to the user's subjective judgment and personal tendencies related to something $(\mathrm{Hu}$ et al., 2019; Lifen Zhao, Koenig-Lewis, Hanmer-Lloyd, \& Ward, 2010). ATT could act as a direct determinant to the intention, but also could be affected by other constructs. Amin (2013) ranked attitude as the dominant factor to predict customer' intention to choose Islamic credit cards. Aboelmaged and Gebba (2013) examined the effects of TAM and TPB variables on the mobile banking adoption, indicating that ATT was the most important predictor. Sanayei and Bahmani (2012) argued that ATT is the second most influential factor that positively affects customer intention to use internet banking in Iran. ATT was found positively and greatly linked with the intention of using mobile banking (Abadi et al., 2012; Raza et al., 2017; Shaikh \& Karjaluoto, 2015). Hu et al. (2019) found the same result when examining factors affecting customer intention to use Fintech services in China.

\section{H3: Attitude has positive impact on Intention}

\subsection{Subjective Norm (SN)}

Ajzen (1991) proposed that the Subjective Norm (SN) refers to the perceived social pressure to perform or not to perform the behavior. According to East (1993) SN is based on salient beliefs about whether particular referents think the respondent should or should not do the action in question. Alhassany and Faisal (2018) compared the total effects of the proposed factors, illustrated that $\mathrm{SN}$ is the second most important predictor that greatly explained intention to use internet banking in North Cyprus. Abadi et al. (2012) found the same result. The significant role of $\mathrm{SN}$ on intention to use mobile banking were discussed in the following studies (Aboelmaged \& Gebba, 2013; Sanayei \& Bahmani, 2012). Amin (2013) also concluded that SN is significantly and positively influences the intention to choose Islamic credit cards. 
H4: Subjective Norm has positive impact on Intention

\subsection{Perceived Behavioral Control (PBC)}

Ajzen (1991) defined Perceived Behavioral Control (PBC) as people's perception of the ease or difficulty of performing the behavior of interest. PBC assesses the degree to which people perceive that they actually have control over enacting the behavior of interest (Aboelmaged \& Gebba, 2013; Ho \& Ko, 2008). Shaikh and Karjaluoto (2015) argued that an integration of TAM and TPB model helps explaining the intention to use mobile banking, and PBC and its antecedents have the most powerful role to predict adoption. Abadi et al. (2012) showed that PBC is the dominant predictor of customer intention to use mobile banking. Takele and Sira (2013) also found that PBC is the most important factor to predict the adoption of customers toward e-banking service. PBC has the positive significant effect on customer intention to use internet banking as found in Rouibah et al. (2011) and Sanayei and Bahmani (2012).

H5: Perceived Behavioral Control has positive impact on Intention

\subsection{Past Experiences (PE)}

Besides the original components being used in TAM and TPB, we decided to utilize two other constructs to further increase the explanatory power of this framework. East (1993) expanded TPB by introducing past behavior and emphasized the direct impact of Past Experiences (PE) on behavioral intention, also found by (Bentler \& Speckart, 1979; Taylor \& Todd, 1995a). Bagozzi and Kimmel (1995) claimed that PE can boost the explanation of TPB model, increasing the prediction of the model towards behavioral intention. Sheeran, Godin, Conner, and Germain (2017) found the effect of PE to be paradoxical. Another reason to utilize PE in our research comes from the fact that the intention to use international bank card may simply be the switch from using domestic card, and exposure to international environment could be a very important determinant in adopting international bank cards.

\section{H6: Past Experiences has positive impact on Intention}

\subsection{Perceived Disadvantages (PD)}

Bauer (1960) introduced the concept of risk, it was organized around the idea that any consumer action will produce consequences that they cannot anticipate with anything approaching certainty. So, perceived risk may be thought of as felt uncertainty regarding possible negative consequences of using a product or service (Featherman \&
Pavlou, 2003). When using services, consumers perceive greater risks, because services are intangibles, nonstandardized and often sold without guarantees or warranties (Clemes, Gan, \& Du, 2012; Murray \& Schlacter, 1990). In the context of bank cards, we would want to further extend the concept of perceived risk to Perceived Disadvantages (PD), which are all the perceived disadvantages that a potential customer think to happen to him/her when using bank cards, not only risk, frauds, but also high charges, purchasing power limitation or limitation of support. Takele and Sira (2013), consistent with GrabnerKräuter and Faullant (2008) found that ATT is explained by perceived risk, while Sanayei and Bahmani (2012) insisted that security risk is the strongest negative predictor of the attitude toward the intention to use internet banking. Abadi et al. (2012) also found evidences that perceived risk negatively affects customers' attitude.

H7a: Perceived Disadvantages has negative impact on Attitude

Clemes et al. (2012) discussed that perceived risks is an important predictor influencing customers' adoption of internet banking in New Zealand. The same result was found in the research of Alhassany and Faisal (2018). Kesharwani and Singh Bisht (2012) concluded that perceived risk negatively influences behavioral intention of internet banking adoption in India. Amin (2013) introduced perceived financial cost, and it has a negative effect on Malaysian bank customers' intention to choose Islamic credit cards.

H7b: Perceived Disadvantages has negative impact on Intention

A complete list of hypotheses is stated below:

\begin{tabular}{|c|c|c|}
\hline Hypothesis & Statement & Previous studies \\
\hline $\mathrm{H} 1 \mathrm{a}$ & $\begin{array}{l}\text { Perceived Ease of } \\
\text { Use has positive } \\
\text { impact on Attitude }\end{array}$ & $\begin{array}{l}\text { Shaikh and Karjaluoto (2015), } \\
\text { Raza et al. (2017), Takele and } \\
\text { Sira (2013), Abadi et al. (2012), } \\
\text { Alhassany and Faisal (2018) }\end{array}$ \\
\hline H1b & $\begin{array}{lr}\text { Perceived } & \text { Ease of } \\
\text { Use has } & \text { positive } \\
\text { impact } & \text { on } \\
\text { Intention } & \end{array}$ & $\begin{array}{l}\text { Takele and Sira (2013), Abadi et } \\
\text { al. (2012), Alhassany and Faisal } \\
\text { (2018), Venkatesh and Davis } \\
\text { (2000), Amin (2007), Rouibah et } \\
\text { al. (2011), Abeka (2012), } \\
\text { Jahangir and Begum (2008) }\end{array}$ \\
\hline $\mathrm{H} 1 \mathrm{c}$ & $\begin{array}{l}\text { Perceived Ease of } \\
\text { Use has positive } \\
\text { impact } \\
\text { Perceived } \\
\text { Usefulness }\end{array}$ & $\begin{array}{l}\text { Hu et al. (2019), Taylor and } \\
\text { Todd (1995b), Rouibah et al. } \\
\text { (2011), Al-Sharafi et al. (2017), } \\
\text { Rogers (2010), Abadi et al. } \\
\text { (2012), Aboelmaged and Gebba } \\
(2013)\end{array}$ \\
\hline $\mathrm{H} 2 \mathrm{a}$ & $\begin{array}{l}\text { Perceived } \\
\text { Usefulness has } \\
\text { positive impact on }\end{array}$ & $\begin{array}{l}\text { Hu et al. (2019), Abadi et al. } \\
\text { (2012), Aboelmaged and Gebba } \\
\text { (2013), Takele and Sira (2013), }\end{array}$ \\
\hline
\end{tabular}




\begin{tabular}{|c|c|c|}
\hline & Attitude & $\begin{array}{l}\text { Sanayei and Bahmani (2012), } \\
\text { Raza et al. (2017). }\end{array}$ \\
\hline $\mathrm{H} 2 \mathrm{~b}$ & $\begin{array}{l}\text { Perceived } \\
\text { Usefulness has } \\
\text { positive impact on } \\
\text { Intention }\end{array}$ & $\begin{array}{l}\text { Taylor and Todd (1995a), Lee } \\
\text { (2009), Sanayei and Bahmani } \\
\text { (2012), Al-Sharafi et al. (2017), } \\
\text { Amin (2007), Amin (2013) }\end{array}$ \\
\hline $\mathrm{H} 3$ & $\begin{array}{l}\text { Attitude has } \\
\text { positive impact on } \\
\text { Intention }\end{array}$ & $\begin{array}{l}\text { Aboelmaged and Gebba (2013), } \\
\text { Amin (2013), Sanayei and } \\
\text { Bahmani (2012), Raza et al. } \\
\text { (2017), Shaikh and Karjaluoto } \\
\text { (2015). Abadi et al. (2012), Hu et } \\
\text { al. (2019) }\end{array}$ \\
\hline $\mathrm{H} 4$ & $\begin{array}{l}\text { Subjective Norm } \\
\text { has positive } \\
\text { impact on } \\
\text { Intention }\end{array}$ & $\begin{array}{l}\text { Alhassany and Faisal (2018), } \\
\text { Abadi et al. (2012), Aboelmaged } \\
\text { and Gebba (2013), Sanayei and } \\
\text { Bahmani (2012), Amin (2013) }\end{array}$ \\
\hline $\mathrm{H} 5$ & $\begin{array}{l}\text { Perceived } \\
\text { Behavioral Control } \\
\text { has positive } \\
\text { impact on } \\
\text { Intention }\end{array}$ & $\begin{array}{l}\text { Shaikh and Karjaluoto (2015), } \\
\text { Abadi et al. (2012), Takele and } \\
\text { Sira (2013), Rouibah et al. } \\
(2011) \text {, Sanayei and Bahmani } \\
(2012)\end{array}$ \\
\hline $\mathrm{H} 6$ & $\begin{array}{l}\text { Past Experiences } \\
\text { has positive } \\
\text { impact on } \\
\text { Intention }\end{array}$ & Bagozzi and Kimmel (1995) \\
\hline $\mathrm{H} 7 \mathrm{a}$ & \begin{tabular}{|l} 
Perceived \\
Disadvantages \\
has negative \\
impact on Attitude
\end{tabular} & $\begin{array}{l}\text { Takele and Sira (2013), Sanayei } \\
\text { and Bahmani (2012), Abadi et } \\
\text { al. (2012), Grabner-Kräuter and } \\
\text { Faullant (2008) }\end{array}$ \\
\hline $\mathrm{H} 7 \mathrm{~b}$ & $\begin{array}{l}\text { Perceived } \\
\text { Disadvantages } \\
\text { has negative } \\
\text { impact on } \\
\text { Intention }\end{array}$ & $\begin{array}{l}\text { Clemes et al. (2012), Alhassany } \\
\text { and Faisal (2018), Kesharwani } \\
\text { and Singh Bisht (2012), Amin } \\
(2013)\end{array}$ \\
\hline
\end{tabular}

\section{Data and Methodology}

\subsection{Methodology}

In order to develop measurements, we designed 8 constructs, based on the adaptation of TPB and TAM, this model built similar constructs to original TPB framework, with Intention to use international bank cards (INT) to be the dependent variables, explanatory variables include Subjective Norms (SN), Perceived Behavioral Control (PBC), Attitude (ATT), Perceived Usefulness (PU) and Perceived Ease of Use (PEU). Regarding bank card specific determinants, we created a new construct, call it Perceived Disadvantages (PD). Finally, due to the fact that we aim at analyzing international bank card, which may happen as a transition from domestic bank card usage, another latent variable, Past Experience (PE) was also integrated in the model.

Being a reflective one, the proposed model was designed with exploratory nature, to evaluate the possibility of an expansion from original TPB framework to fit in to the context of bank card service. As the result, we employed the PLS - SEM approach for our research, using SmartPLS 3.2.8 software for statistical analyses. Figure 1 depicts the inner and outer models for our proposed research framework.

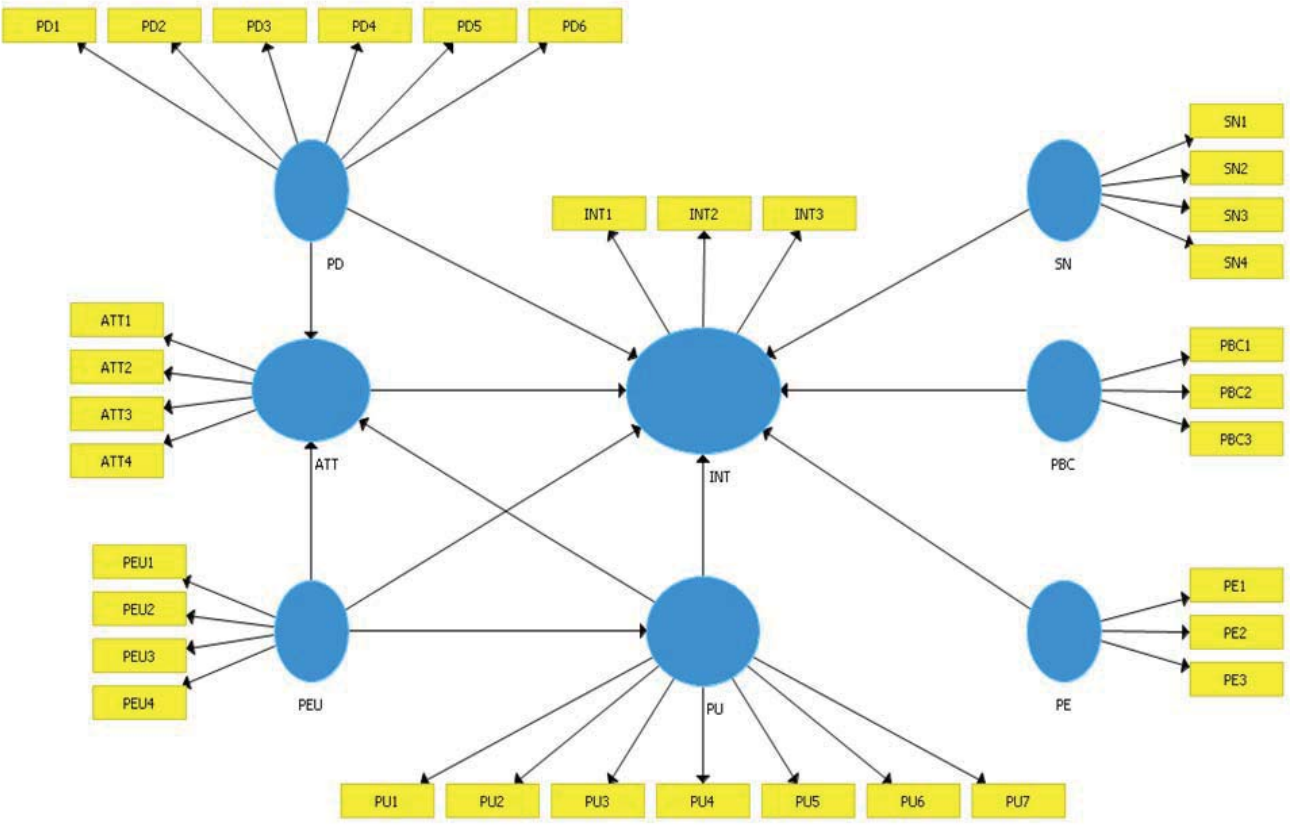

Figure 1: Proposed Model for Intention 


\subsection{Data}

Data for this research were collected by using surveys, targeted respondents are from Hanoi and Ho Chi Minh City, two biggest cities in Vietnam. With the help of collaborators, students from major economic universities and customers of large commercial banks in Hanoi and Ho Chi Minh City were invited to take the survey. Online surveys were distributed via Google Forms platform and offline surveys were distributed directly to respondents.

Preliminary surveys were provided to a group of volunteers, after minor adjustment, official surveys were sent to potential respondents. All of the online surveys were valid, and some of the offline surveys were discarded due to missing values, resulting to 619 valid answers. Table 1 displays the demographic characteristics of respondents. More than $56 \%$ of participants were female and $44 \%$ were male, about $40 \%$ of the respondents were student, reflecting the fact that universities are included as one of the major data gathering locations. Office staffs and professionals took up to $53 \%$ of the respondents, and the remaining were either freelancers or doing housework. Correspondingly, the age distribution fit age characteristics, with a dominant $44 \%$ aged 18-22, people aged $23-40$ totally took $48 \%$. Approximately $50 \%$ of the respondents had income of less than 5 million VND a month (by the time being 1USD = approx. 23,000 VND), most of them fell in to the "Student" category, with very little or no income. However, once they are graduated, their income distribution is dramatically changed, bearing in mind that the average monthly income in Vietnam at the moment is approximately 5.6 million VND.
Table 1: Demographic Description

\begin{tabular}{|c|c|c|c|}
\hline Measure & Item & Count & Percentage \\
\hline Gender & Female & 349 & $56.38 \%$ \\
\hline & Male & 270 & $43.62 \%$ \\
\hline Job & Freelance\&Other & 27 & $4.36 \%$ \\
\hline & Housework & 11 & $1.78 \%$ \\
\hline & Office & 225 & $36.35 \%$ \\
\hline & Professional & 103 & $16.64 \%$ \\
\hline Age & Student & 253 & $40.87 \%$ \\
\hline & $>40$ & 47 & $7.59 \%$ \\
\hline & $18-22$ & 272 & $43.94 \%$ \\
\hline & $23-30$ & 160 & $25.85 \%$ \\
\hline Income & $31-40$ & 140 & $22.62 \%$ \\
\hline (monthly) & $<5 \mathrm{mil}$ & 308 & $49.76 \%$ \\
\hline & $>20 \mathrm{mil}$ & 41 & $6.62 \%$ \\
\hline & $10-20 \mathrm{mil}$ & 181 & $29.24 \%$ \\
\hline & $5-10 \mathrm{mil}$ & 89 & $14.38 \%$ \\
\hline
\end{tabular}

\section{Empirical Results}

\subsection{Proposed Model Output}

After preliminary run using PLS algorithm, some indicators failed to meet the requirement of construct reliability with loadings of less than 0.7 , in which PD1, PD6, PU5 and PE1 have values between 0.4 and 0.7, Hair, Risher, Sarstedt, and Ringle (2019) suggested that these indicators should be removed if AVE and CR are increased after elimination. According to that, all of these above indicators were discarded to guarantee validity of the overall model, with higher $C R$ and $A V E$ values, which leads to a reduced model, depicted in Figure 2.

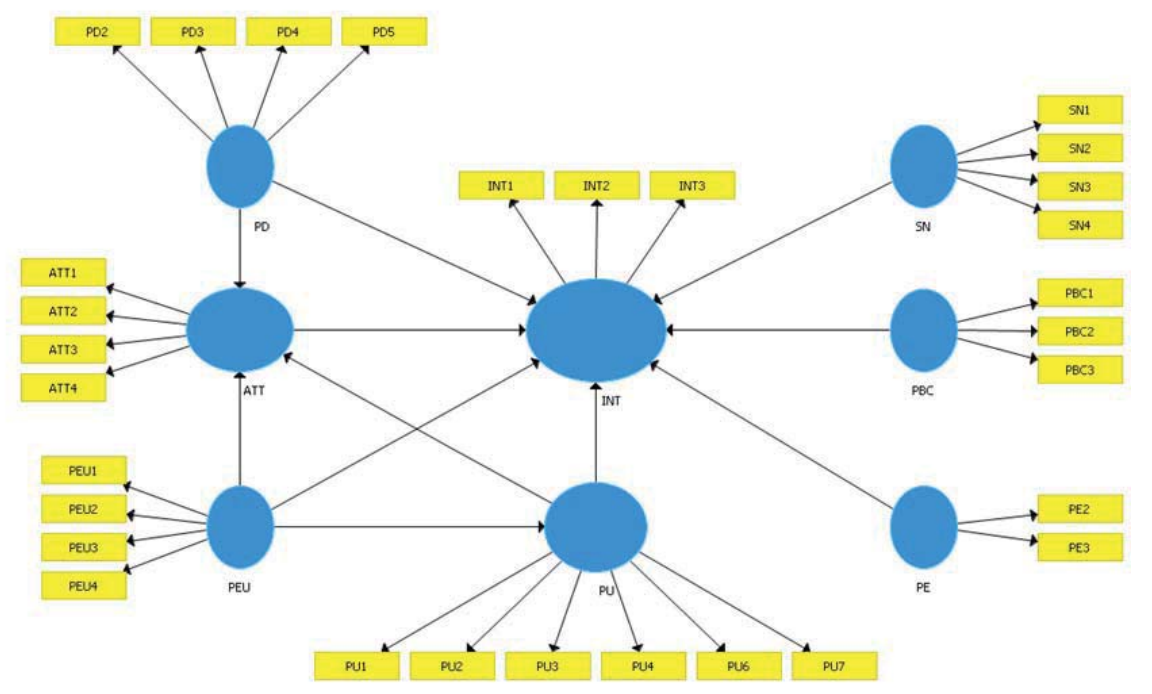

Figure 2: Reduced model 


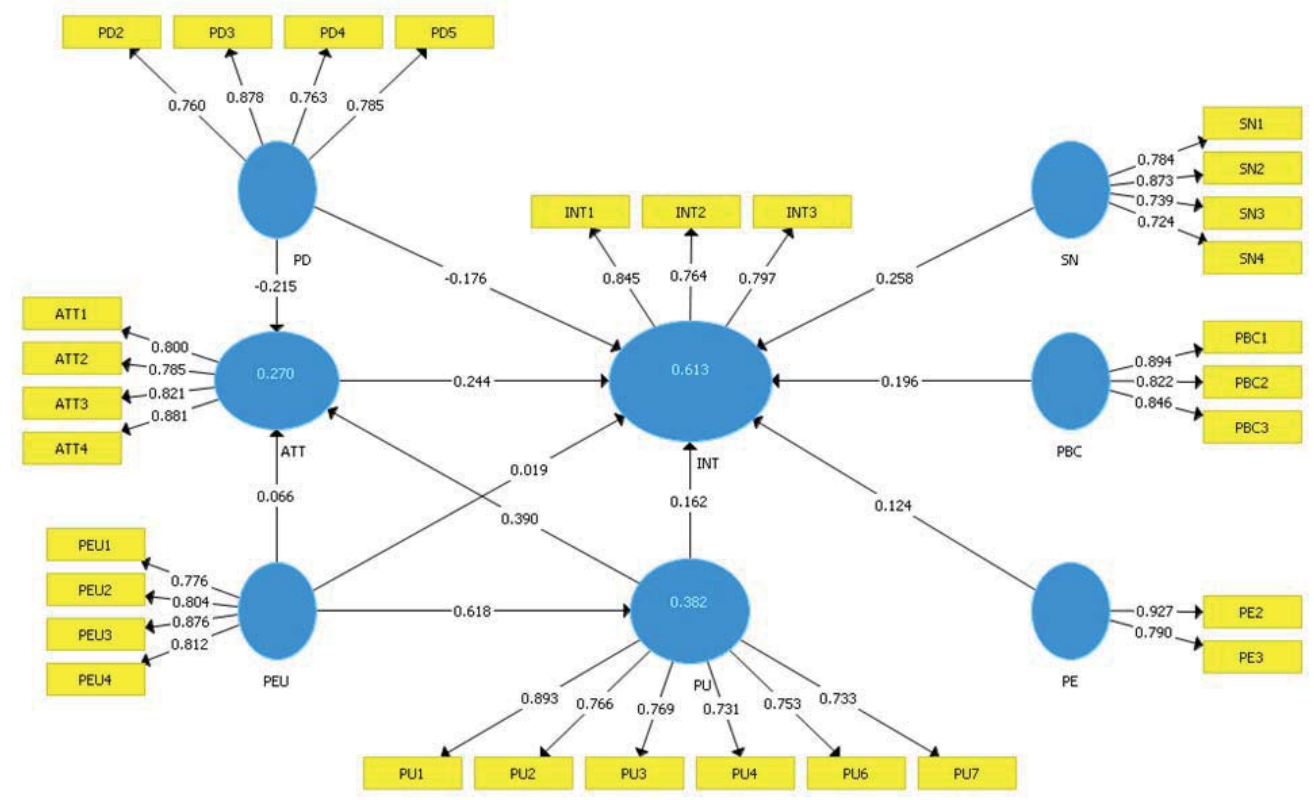

Figure 3: Reduced Model Output

\subsection{Assessment of Measurement Model}

As shown in Figure 3, all indicators in the reduced model have loadings higher than 0.706 , indicating that all constructs are able to reliably explain more than $50 \%$ of the contained indicators. Table 2 provides more evidences of internal consistency reliability of the model, with composite reliability $(C R)$ values are in the range of 0.7 to 0.9 , meaning "satisfactory to good reliability" (Jöreskog, 1971). Some other authors propose Cronbach's Alpha as another criterion to assess reliability, in which PE fails to achieve the minimum level of 0.7 , but we reckon that $C R$ shall be sufficient and is advantageous to $C R$ in evaluating reliability as explained in Hair et al. (2019). Convergence validity of the model is also satisfactory, meaning that all constructs converge to explain variance of the items. Average Variance Extracted (AVE) values are all higher than 0.5 , as mentioned in Hair et al. (2019).

Table 2: Reliability and Validity measures

\begin{tabular}{|c|c|c|c|c|}
\hline Item & Cronbach's Alpha & rho_A & CR & AVE \\
\hline PD & 0.809 & 0.819 & 0.875 & 0.637 \\
\hline ATT & 0.840 & 0.850 & 0.893 & 0.676 \\
\hline INT & 0.722 & 0.726 & 0.844 & 0.644 \\
\hline PU & 0.867 & 0.876 & 0.900 & 0.602 \\
\hline PBC & 0.815 & 0.824 & 0.890 & 0.730 \\
\hline PE & 0.669 & 0.781 & 0.851 & 0.742 \\
\hline PEU & 0.834 & 0.841 & 0.890 & 0.669 \\
\hline SN & 0.788 & 0.812 & 0.862 & 0.612 \\
\hline
\end{tabular}

Last assessment of the measurement model, discriminant validity, could be validated using multiple methods, including Cross loads, Fornell-Larcker criterion, in this paper we use Henseler, Ringle, and Sarstedt (2015)'s HeterotraitMonotrait ratio (HTMT), according to this criterion, HTMT values cannot be too high to avoid having discriminant problems. All HTMT values in Table 3 are below 0.9 , satisfy the maximum threshold of this criterion.

Table 3: HTMT scores for discriminant validity

\begin{tabular}{|c|c|c|c|c|c|c|c|}
\hline Item & ATT & PEU & INT & PBC & PD & PE & PU \\
\hline PEU & 0.356 & & & & & & \\
\hline INT & 0.603 & 0.736 & & & & & \\
\hline PBC & 0.221 & 0.550 & 0.612 & & & & \\
\hline PD & 0.411 & 0.409 & 0.685 & 0.358 & & & \\
\hline PE & 0.385 & 0.311 & 0.569 & 0.222 & 0.402 & & \\
\hline PU & 0.162 & 0.399 & 0.469 & 0.722 & 0.338 & 0.135 & \\
\hline SN & 0.362 & 0.476 & 0.760 & 0.385 & 0.473 & 0.434 & 0.338 \\
\hline
\end{tabular}

\subsection{Assessment of Structural Model}

As measurement model assessments are satisfactory, the next step we follow is assessing the structural model. Collinearity check of the constructs was conducted using Variance Inflation Factor (VIF), Table 4 shows that all VIF measures are below, meaning that there is no potential multicollinearity problem. 
Table 4: VIF values for inner model

\begin{tabular}{|c|c|c|c|c|c|c|c|c|}
\hline Item & PD & ATT & INT & PU & PBC & PE & PEU & SN \\
\hline PD & & 1.038 & 1.239 & & & & & \\
\hline ATT & & & 1.477 & & & & & \\
\hline INT & & & & & & & & \\
\hline PU & & 1.647 & 1.878 & & & & & \\
\hline PBC & & & 1.360 & & & & & \\
\hline PE & & & 1.227 & & & & & \\
\hline PEU & & 1.619 & 1.657 & 1.000 & & & & \\
\hline SN & & & 1.396 & & & & & \\
\hline
\end{tabular}

The coefficients of determination $\left(R^{2}\right)$ were found satisfactory, with ATT of 0.270 , INT of 0.613 and PU of 0.382 . The model could explain $61.3 \%$ the variance of Intention, showing high overall explanatory power. $27 \%$ of ATT is jointly explained by PEU and PU, and PEU itself could explain $38.2 \%$ of PU. Bootstrapping method in SmartPLS3 shows that all confidence $t$-values are strongly higher than 1.96, except for PEU $\rightarrow$ ATT (t-values of 1.299) and $\mathrm{PEU} \rightarrow \mathrm{INT}$ ( $t$-values of 0.634 ), confirming that almost all construct validity are statistically significant.

To assess out-of-sample prediction power, the blindfolding-based cross-validated redundancy measure $Q^{2}$ values of the relevant constructs were calculated, all values are higher than 0 , with ATT of 0.171 , INT of 0.372 and PU of 0.215. According to Geisser (1974), ATT, PU and INT have small predictive relevance for the PLS-path model.

\section{Discussions}

By using expanded decomposed TAM-TPB Model, we have found evidences supporting our hypotheses. All of the latent variables except PEU have significant direct impact on the intention to use international bank card of Vietnamese users with the explanatory power of $61.3 \%$. Among the constructs, $\mathrm{SN}$ has strongest direct impact on INT with path coefficient of 0.258 , supporting $H 4$, and this result reflects the fact that potential customers are strongly affected by recommendations and promotion programs in their decision to use international bank card, and by their bankers. This result is in line with Alhassany and Faisal (2018) and also Abadi et al. (2012).

ATT have similar direct impact on INT, with the value of 0.244, Abadi et al. (2012), and Takele and Sira (2013) have also found positive and statistically significant impact by ATT on INT, and this paper have found the same conclusion, supporting H3. Besides, ATT is significantly explained negatively by PD (with coefficient of -0.215) in line with Abadi et al. (2012) and Takele and Sira (2013), while PU $(0.390)$ has positive impacts which underscores the findings of the following studies (Aboelmaged \& Gebba, 2013; Hu et al., 2019; Raza et al., 2017; Sanayei \& Bahmani, 2012), confirming that attitude is affected by other independent variables while being an independent variable toward intention, supporting $\mathrm{H} 2 \mathrm{a}$ and $\mathrm{H} 2 \mathrm{~b}$.

Despite having adequate direct impact, $\mathrm{PU}$ also has indirect impact on INT via ATT, which leads to strong total impact of 0.257 , supporting $\mathrm{H} 2 \mathrm{a}$ and $\mathrm{H} 2 b$, this mechanism was also found in the following studies (Abadi et al., 2012; Cheng et al., 2006; Lee, 2009; Raza et al., 2017; Sanayei \& Bahmani, 2012; Takele \& Sira, 2013). Since the product of interest is international bank card, one of the major concerns from the perspective of users should be how useful it is to become a replacement for their current transaction instruments such as cash and domestic bank cards, bearing in mind that Vietnam is cash-intensive when it comes to means of payment.

PE has a moderate impact of 0.124 , suggesting that past experience/ exposure to international environment has an effect on the intention to adopt international bank card, confirming H6. However, one dropped indicator (PE1), which is the frequency of using domestic bank card in transaction, has shown non-consensus responses. In our point of view, this comes from the fact in Vietnam that a very high portion of domestic bank card users barely use cards for purchasing items. The only reason they own a card is because their companies pay salary to their bank account, and they use the card to withdraw cash. It is consistent with our above argument that Vietnam is still a cash-based economy. For this group of user, having a past experience with domestic card does not increase the intention of using international bank cards.

PBC, with path coefficient of 0.196 , was found to have positive impact on INT, underscoring $H 5$. Evidences of over confidence were found in Vietnamese market, as in Phan and Pham (2019) and it is explainable why PBC has significant impact on intention, this result is also consistent with the following studies (Abadi et al., 2012; Rouibah et al., 2011; Sanayei \& Bahmani, 2012; Shaikh \& Karjaluoto, 2015; Takele \& Sira, 2013).

Interestingly enough, PD, a newly introduced construct, has a significant total effect of -0.228 , in which the direct impact is -0.176 , showing $H 7 a$ and $H 7 b$ supported. It is consistent with our initial argument when setting up this construct that for international bank cards, exposure to risk, and also to other disadvantages is considered as one of the major concern of potential bank card users, especially when it comes to international environment.

PEU was found to have nonsignificant direct impact on INT and ATT, but PEU has strong positive impact on PU, with coefficient of 0.618 , supporting $\mathrm{H} 1 \mathrm{c}$ but leaving $\mathrm{H} 1 \mathrm{a}$ and $H 1 b$ unsupported. This result is consistent with the 
findings of the following studies (Aboelmaged \& Gebba, 2013; Al-Sharafi et al., 2017; Hu et al., 2019).

\section{Conclusions and Limitations}

Overall, all findings reveal that in general, intention to adopt international bank card is affected by almost all factors, leave alone PEU, three constructs with strongest impacts are SN, PU and PD. In the context of current Vietnamese bank card market, with high cash intensity and fragile customers' trust, it is reasonable for those to be the main determinants of behavioral intention, sending signals to card issuers for a proper market approach strategy.

This paper focuses on the intention to adopt international bank card in Vietnam, which is a market with growing market share for the product, but it could be a better combination if the scope of consideration considers state of the art products: mobile wallets, cryptocurrencies etc. A next phase could be further embedded in the model, which is the transformation of intention to use to the decision to user. Other authors have proposed an integrated model, comparing and combining popular intention assessment models such as TPB, TAM, UTAUT, etc. This could also be a suggestion for future development of the research. Other authors mentioned the effect of demographic characteristics on INT (Lee \& Cormier, 2010; Onyia \& Tagg, 2011), however in this paper, we did not employ that approach, this could be another suggestion for future research direction.

\section{References}

Abadi, H. R. D., Ranjbarian, B., \& Zade, F. K. (2012). Investigate the customers' behavioral intention to use mobile banking based on TPB, TAM and perceived risk (a case study in Meli Bank). International Journal of Academic Research in Business and Social Sciences, 2(10), 312-322.

Abeka, S. O. (2012). Perceived usefulness, ease of use, organizational and bank support as determinants of adoption of internet banking in east Africa. International Journal of Academic Research in Business and Social Sciences, 2(10), 97-112.

Aboelmaged, M., \& Gebba, T. R. (2013). Mobile banking adoption: An examination of technology acceptance model and theory of planned behavior. International Journal of Business Research and Development, 2(1), 3550.
Ajzen, I. (1991). The theory of planned behavior. Organizational Behavior and Human Decision Processes, 50(2), 179-211.

Ajzen, I., \& Fishbein, M. (1980). Understanding attitudes and predicting social behaviour. Englewood Cliffs, NJ: Prentice-Hall.

Akturan, U., \& Tezcan, N. (2012). Mobile banking adoption of the youth market: Perceptions and intentions. Marketing Intelligence \& Planning, 30(4), 444-459.

Al-Sharafi, M. A., Arshah, R. A., Herzallah, F. A., \& Alajmi, Q. (2017). The Effect of Perceived Ease of Use and Usefulness on Customers Intention to Use Online Banking Services: The Mediating Role of Perceived Trust. International Journal of Innovative Computing, 7(1), 9-14.

Alhassany, H., \& Faisal, F. (2018). Factors influencing the internet banking adoption decision in North Cyprus: an evidence from the partial least square approach of the structural equation modeling. Financial Innovation, 4(1), 29-49.

Amin, H. (2007). An analysis of mobile credit card usage intentions. Information Management \& Computer Security, 15(4), 260-269.

Amin, H. (2013). Factors influencing Malaysian bank customers to choose Islamic credit cards: empirical evidence from the TRA model. Journal of Islamic Marketing, 4(3), 245-263.

Bagozzi, R. P., \& Kimmel, S. K. (1995). A comparison of leading theories for the prediction of goal-directed behaviours. British Journal of social psychology, 34(4), 437-461.

Bauer, R. A. (1960). Consumer Behavior as Risk Taking. In: R. S. Hancock (Ed.), Dynamic Marketing for a Changing World. Proceedings of the 43rd. Conference of the American Marketing Association, 389-398.

Bentler, P. M., \& Speckart, G. (1979). Models of attitudebehavior relations. Psychological Review, 86(5), 452-464.

Cheng, T. E., Lam, D. Y., \& Yeung, A. C. (2006). Adoption of internet banking: an empirical study in Hong Kong. Decision Support Systems, 42(3), 1558-1572.

Clemes, M. D., Gan, C., \& Du, J. (2012). The factors impacting on customers' decisions to adopt Internet banking. Banks and Bank Systems, 7(3), 1-13.

Davis, F. D. (1989). Perceived usefulness, perceived ease of use, and user acceptance of information technology. MIS Quarterly, 13, 319-340.

East, R. (1993). Investment decisions and the theory of planned behaviour. Journal of Economic Psychology, 14(2), 337-375.

Featherman, M. S., \& Pavlou, P. A. (2003). Predicting eservices adoption: a perceived risk facets perspective. International Journal of Human-computer Studies, 59(4), 451-474. 
Geisser, S. (1974). A predictive approach to the random effect model. Biometrika, 61(1), 101-107.

Giao, H. N. K. (2019). Customer Satisfaction towards ATM Services: A Case of Vietcombank Vinh Long, Vietnam. Journal of Asian Finance, Economics and Business, 6(1), 141-148.

Grabner-Kräuter, S., \& Faullant, R. (2008). Consumer acceptance of internet banking: the influence of internet trust. International Journal of Bank Marketing, 26(7), 483504.

Hair, J. F., Risher, J. J., Sarstedt, M., \& Ringle, C. M. (2019). When to use and how to report the results of PLS-SEM. European Business Review, 31(1), 2-24.

Henseler, J., Ringle, C. M., \& Sarstedt, M. (2015). A new criterion for assessing discriminant validity in variancebased structural equation modeling. Journal of the Academy of Marketing science, 43(1), 115-135.

Ho, S.-H., \& Ko, Y.-Y. (2008). Effects of self-service technology on customer value and customer readiness: The case of Internet banking. Internet Research, 18(4), 427-446.

Hu, Z., Ding, S., Li, S., Chen, L., \& Yang, S. (2019). Adoption Intention of Fintech Services for Bank Users: An Empirical Examination with an Extended Technology Acceptance Model. Symmetry, 11(3), 340-355.

Jahangir, N., \& Begum, N. (2008). The role of perceived usefulness, perceived ease of use, security and privacy, and customer attitude to engender customer adaptation in the context of electronic banking. African Journal of Business Management, 2(2), 032-040.

Jöreskog, K. G. (1971). Simultaneous factor analysis in several populations. Psychometrika, 36(4), 409-426.

Kesharwani, A., \& Singh Bisht, S. (2012). The impact of trust and perceived risk on internet banking adoption in India: An extension of technology acceptance model. International Journal of Bank Marketing, 30(4), 303-322.

Lee, J. W., \& Cormier, J. (2010). Effects of Customers' Demographic Profile on Mobile Commerce Adoption. Journal of Distribution Science, 8(1), 5-11.

Lee, M. C. (2009). Factors influencing the adoption of internet banking: An integration of TAM and TPB with perceived risk and perceived benefit. Electronic Commerce Research and Applications, 8(3), 130-141.

Lifen Zhao, A., Koenig-Lewis, N., Hanmer-Lloyd, S., \& Ward, P. (2010). Adoption of internet banking services in China: is it all about trust? International Journal of Bank Marketing, 28(1), 7-26.

Lin, C., \& Nguyen, C. (2011). Exploring e-payment adoption in Vietnam and Taiwan. Journal of Computer Information Systems, 51(4), 41-52.

Murray, K. B., \& Schlacter, J. L. (1990). The impact of services versus goods on consumers' assessment of perceived risk and variability. Journal of the Academy of Marketing science, 18(1), 51-65.

Onyia, O. P., \& Tagg, S. K. (2011). Effects of demographic factors on bank customers' attitudes and intention toward Internet banking adoption in a major developing African country. Journal of Financial Services Marketing, 16(3-4), 294-315.

Pham, L., Cao, N. Y., Nguyen, T. D., \& Tran, P. T. (2013). Alternative Structural Models for E-Banking Adoption in Vietnam. Academy of Business Research Journal, 2, 6486.

Phan Tran Trung, D., \& Pham Quang, H. (2019). Adaptive Market Hypothesis: Evidence from the Vietnamese Stock Market. Journal of Risk and Financial Management, 12(2), 81-96.

Raza, S. A., Umer, A., \& Shah, N. (2017). New determinants of ease of use and perceived usefulness for mobile banking adoption. International Journal of Electronic Customer Relationship Management, 11(1), 44-65.

Rogers, E. M. (2010). Diffusion of innovations. New York, NY: Simon and Schuster.

Rouibah, K., Ramayah, T., \& May, O. S. (2011). Modeling user acceptance of internet banking in Malaysia: A partial least square (PLS) approach. In E-adoption and socioeconomic impacts: Emerging infrastructural effects (pp. 123). Hershey, PA: IGI Global.

Ryu, H.-S. (2018). What makes users willing or hesitant to use Fintech?: the moderating effect of user type. Industrial Management Data Systems, 118(3), 541-569.

Şafakli, O. V. (2007). Motivating factors of credit card usage and ownership: evidence from Northern Cyprus. Investment Management Financial Innovations, 4(4), 133143.

Sanayei, A., \& Bahmani, E. (2012). Integrating TAM and TPB with perceived risk to measure customers' acceptance of internet banking. International Journal of Information Science and Management, (ECDC 2012), 2537.

Shaikh, A. A., \& Karjaluoto, H. (2015). Mobile banking adoption: A literature review. Telematics and Informatics, 32(1), 129-142.

Sheeran, P., Godin, G., Conner, M., \& Germain, M. (2017). Paradoxical effects of experience: Past behavior both strengthens and weakens the intention-behavior relationship. Journal of the Association for Consumer Research, 2(3), 309-318.

Takele, Y., \& Sira, Z. (2013). Analysis of factors influencing customers'intention to the adoption of e-banking service channels in bahir dar city: an integration of tam, tpb and pr. European Scientific Journal, 9(13), 402-417.

Taylor, S., \& Todd, P. (1995a). Assessing IT usage: The role of prior experience. MIS Quarterly, 19, 561-570. 
Taylor, S., \& Todd, P. A. (1995b). Understanding information technology usage: A test of competing models. Information Systems Research, 6(2), 144-176.

Venkatesh, V., \& Davis, F. D. (2000). A theoretical extension of the technology acceptance model: Four longitudinal field studies. Management Science, 46(2), 186-204.
Venkatesh, V., Morris, M. G., Davis, G. B., \& Davis, F. D. (2003). User acceptance of information technology: Toward a unified view. MIS Quarterly, 27, 425-478.

Wang, J.-S., \& Pho, T.-S. (2009). Drivers of customer intention to use online banking: An empirical study in Vietnam. African Journal of Business Management, 3(11), 669-677. 